\title{
CREATING SUSTAINABILITY NATURAL TOURISM DESTINATION
}

\author{
Yunita ISMAIL* \\ President University, Environmental Engineering Study Program, \\ Faculty of Engineering, Ki Hajar Dewantara, Cikarang, Indonesia, e-mail: yunitaismail@ president.ac.id
}

\begin{abstract}
Citation: Ismail, Y. (2021). CREATING SUSTAINABILITY NATURAL TOURISM DESTINATION. GeoJournal of Tourism and Geosites, 39(4spl), 1331-1335. https://doi.org/10.30892/gtg.394spl02-775
\end{abstract}

\begin{abstract}
Indonesia have many beautiful natural view but there are still a lot of un explore and unnoticed natural tourism destination to be discovered. That has potential for tourism. There are several natural tourism destination that already well-known, such as Bali, Bintan or Raja Ampat, but still have more natural tourism destination still have original a very view and not really noted. In this research, Sawarna Beach chosen as a research location. Sawarna Beach is very beautiful beach with various coastal characteristics. This beach has a complex and unique physiography, morphology and geological setting. The geological wealth of Sawarna coast can be a tremendous asset for tourism. This location has an outstanding potential to become a favorite tourist destination, given the natural beauty displayed. Sampling method used purposively method, data were collected by direct observations and interview, then the data were analyzed descriptively. The physical condition of the Sarwana Beach area is still not polluted, considering that the physical characteristics of the water on these areas are still below the threshold. The socio-economic conditions of the people in the Bayah area needs to be improved. The development itself is provide tourism services from the community is low considering that tourism development in this region is low. Lodging facilities have begun to develop but are limited to lodging, there are no hotels. The restaurants are limited to small restaurants that are not well organized. Local government efforts to organize natural tourism areas only need to be increased and carried out comprehensively. Efforts to make Sawarna Beach as a sustainable touri st de stinations can be achieved with the joint efforts of all parties including the community, government and academia.
\end{abstract}

Key words: natural tourism, sustainability, physical condition, socio-economic conditions

\section{INTRODUCTION}

Tourist destinations that feature natural beauty can be excellent for Indonesia, which is an archipelago with all its diverse ecosystems and cultures. The area of Bayah District, Banten Regency is an area in the south of the island of Java, has a coastal area facing the Indian Ocean with a long coastline and has a variety of different coastal views. The area of Bayah District is part of the southern mountainous zone of West Java which is composed of hundreds of years old volcanic rocks. The beauty of the beach in Bayah Subdistrict, especially Sarwana Village, has not yet contributed to the welfare of the community. According to data from the Central Bureau of Statistics of Bayah District, the livelihoods of residents in this sub-district are farmers, farm laborers, fishermen, fishing laborers, industry, construction, trade, transportation, mining / quarrying, civil servants, military, police, etc. The tourism sector is yet to be one of the people's livelihoods in this sub-district (BPS Bayah sub District, 2019). The distribution of the population

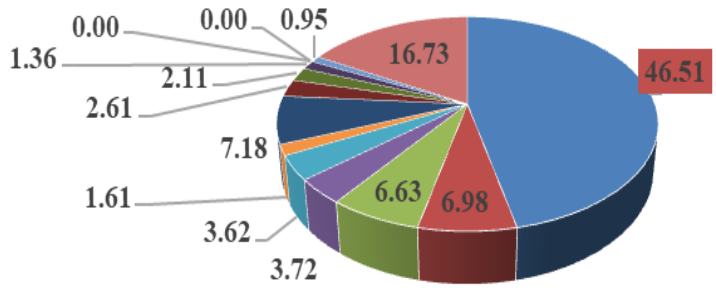

- Falmes

- Fishing laborer's

- Trade

Figure 1. Distribution of Bayah District Population Percentage based based on their livelihoods is shown in Figure 1. Thus, Livelihoods (\%) (Source: Kecamatan Bayah Dalam Angka 2019, 2019) the contribution of the tourism sector to regional income (GDP) is not yet visible. Mostly resident of Kecamatan Bayah is farmers $(46.51 \%)$, and farms workers $(6.98 \%)$. Agricultural crops are dominated by rice, both lowland rice (641 ha of harvested area in 2018) and lading rice (27 ha of harvested area in 2018). The dominant plantation crop is coconut because this area is a good coastal area for coconut tree growth. The beach that belongs to the Bayah sub-district, especially the Sarwana village, is unique, which is rarely found on other beaches. Figure 2 shows some of the coastal views found in Sarwana beach. From Figure 2, you can see the potential for beach views in several places in the village of Sawarna which are very unique and interesting as tourist objects. However, it needs better attention, the development of this tourism needs more attention in order to provide benefits to all people in this village without damaging the environment. Therefore, the aim of this paper is to present the potential for tourism development in Sarwana village in a descriptive manner.

\section{LITERATURE REVIEW}

Tourism as one of the sectors that makes a major contribution to the development of the Indonesian economy, like in

\footnotetext{
* Corresponding author
} 
European United countries, tourism plays a significant role in promoting economic growth of both Eastern and Western EU countries (Paramati et al., 2017). The tourism development must consider the carrying capacity of tourist areas, especially for nature tourism. Harmony between tourism development and the environment is dynamically changing, coupling factors between the environment and tourism will greatly determine the use of the environment for tourism (Tang, 2015).
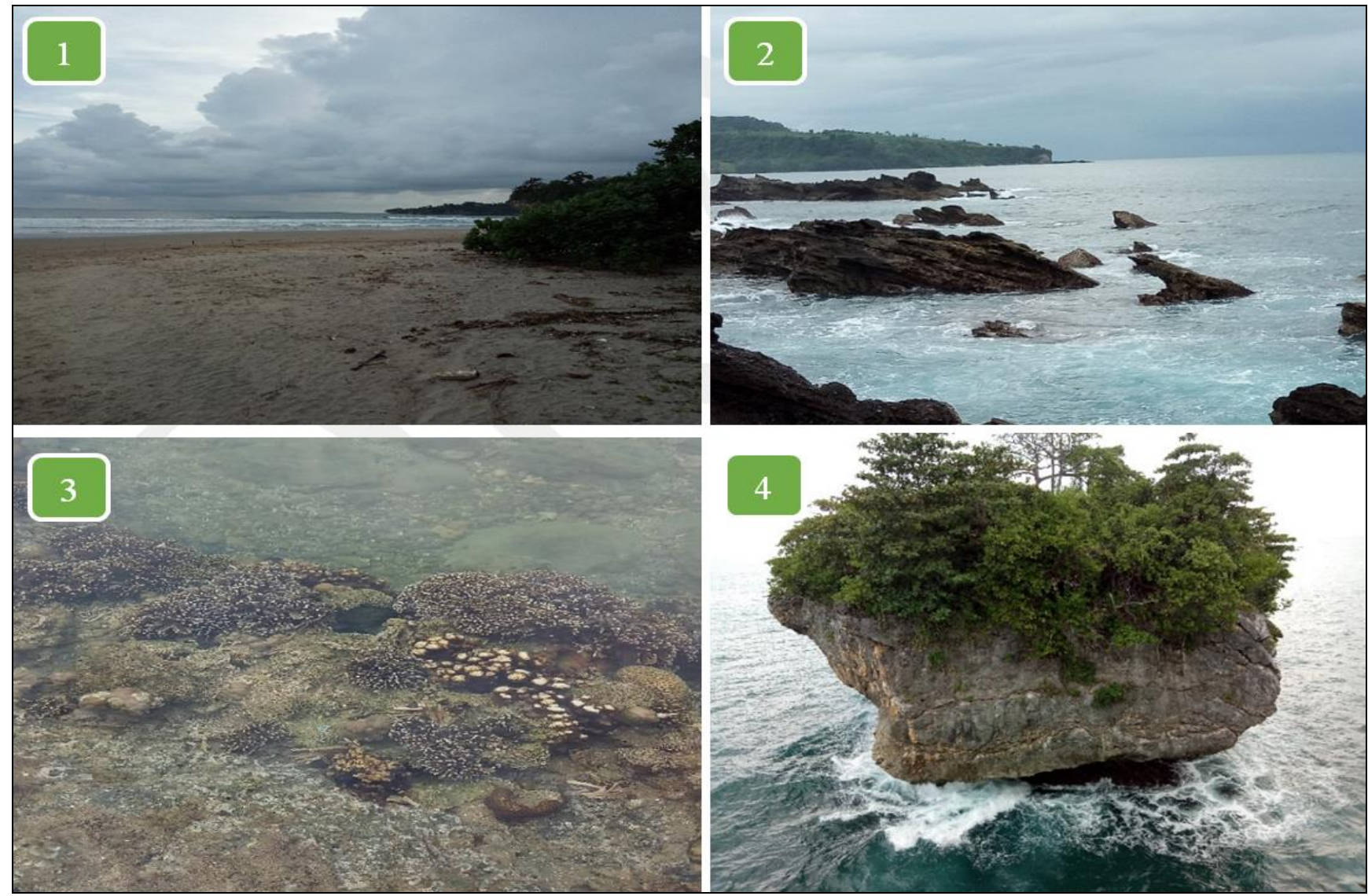

Figure 2. Beach view in Sarwana Village (Source: Ismail, 1 Sandy Beach, 2,3,4 Rocky Beach, Sarwana Beach, Banten, Indonesia )

For sustainable tourism, it important to analyze the dynamic relationship between tourism and environmental quality (Danish and Wang, 2018). Excessive use of nature for tourism will have a negative impact on nature itself. There is a positive correlation between the environmental knowledge and the environmental attitude, a positive correlation between the environmental attitude and the environmental behaviour, and a positive correlation between the environmental knowledge and the environmental behaviour (Zheng et al., 2018). That will beneficial for culturing common people's environmental literacy, correct environmental attitude, environmental and ecological caring, and fulfilment of environmental behaviour. The competitiveness of tourism destination also determined by several economic, geographical, cultural, and political features (Gómez-Vega and J Picazo-Tadeo, 2019). From research of (Armenski et al., 2018), there are five dimensions for

\section{TOURISM}

Mass Tourism - large numbers of people seeking replication of their ov/n culture in institutionalised settings. wildlife tourism in captivity or artificial settings

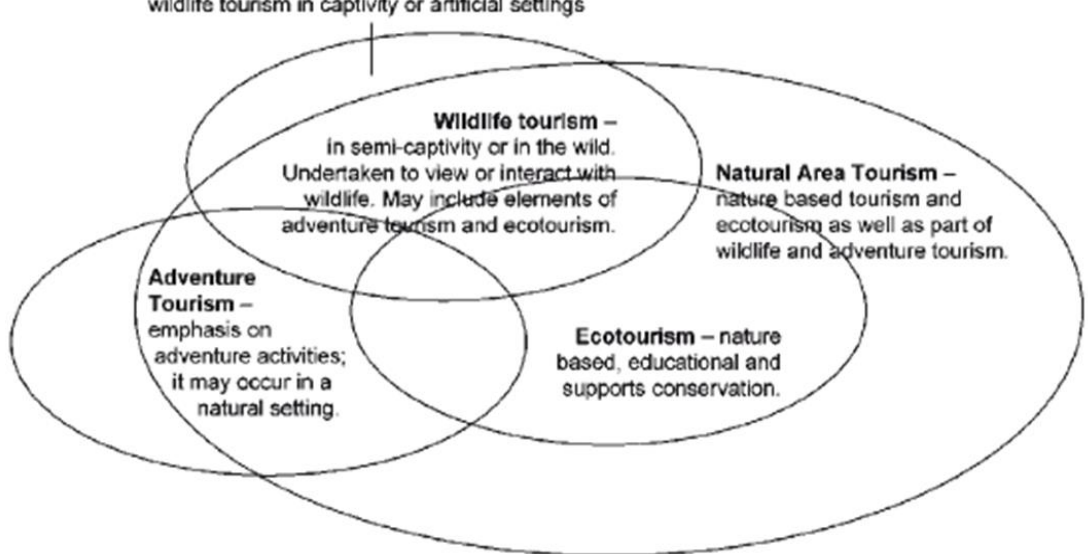

Alternative Tourism- forms of tourism generally characterized by small scale sustainable activities

Figure 3. Relationship of ecotourism to other forms of tourism (Source: Hill and Gale, 2012)
Serbian competitiveness, risk management and adaptive environmental strategies, innovation and product development, planning for sustainable development, networking and community concern and education for sustainability. The study of pollution caused by tourism activities is an important thing to study. Based on (Ahmad et al., 2018), natural environment and scenic points in western part of China are an attraction for tourists but strict regulations are required to promote the positive impact of tourism. environmentfriendly tourism. The relationship of ecotourism to other of tourism show at Figure 3. From Figure 3, ecotourism could have relationship with another type of tourism, and this relationship could give a good impact to environment. The natural tourism or wildlife tourism must 
keep the environment to support the experience and the amenities that offer by environment. In Bayah Beach, there are ecotourism such as cave that as a field laboratory for geology and used by geology student and lecturer for their research and teaching activities. The location of the cave is near the sandy beach that shown natural area tourism. The improvement in policies and regulations will increase tourism growth, although when tourism increases, so does, in turn, contamination of the environment, so that the relationship between tourism and environmental sustainability is shown to be bidirectional (Pulido-Fernández et al., 2019). There is significant and positive influence of environmental sustainability on tourism growth, the association factor is relatively low, indicating that there are other factors that affect tourism growth (obviously, the development of tourism is also affected by the quality of the accommodation on offer, the number of tourist resources, or the accessibility of the destination, among other factors). In the coupling coordination analysis between tourism and the environment it is found that the harmonious development of tourism and the environment system is a dynamic, analysis of coupling coordination in Heilongjiang Province, China from 1995 to 2012 showed is that the trend to ascend in general (Tang, 2015). Based on (Sun, 2019), the relationship between tourism and global value chains (GVCs) that GVCs increase a nation's tourism carbon competitiveness and relieve global carbon pressure. From an environmentally extended input-output model that assess the distribution of the tourism's economic and environmental effects in global segments find that high in carbon contents but low in economic linkage. In tourism development needs to facilitate the transition of domestic businesses toward better energy efficiency, and produced with a lower carbon intensity than the domestic production technology. Linkage between the natural ecosystem and economic ecosystem in tourism development might use industrial ecology approach (Lucchetti and Arcese, 2014).

\section{MATERIALS AND METHODS}

In this research, Sawarna Beach were chosen deliberately, because in these areas, the tourism industry has started but has not been yet to be maximized and the environmental quality in this area must be maintained. Environmental aspects that measured in this research is water physical characteristics. At Sawarna Beach area, the water sample is taken at 4 points, which are Gua Langir, Pulau Manuk, Cisawarna and Ciasem. The consideration in choosing the sample point is these points have different condition and would represent the whole area. The parameters measured were turbidity, conductivity, $\mathrm{pH}$ and temperature, with 3 replication for each point. For social and economics aspect, respondent chosen purposively. Informant at Sawarna Beach is the guide who has been a tour guide for about 15 years, his name is Mr. Baduy. The method used to collect the data was interview with question guide and method used to analyze was descriptive (Biggs et al., 2021).

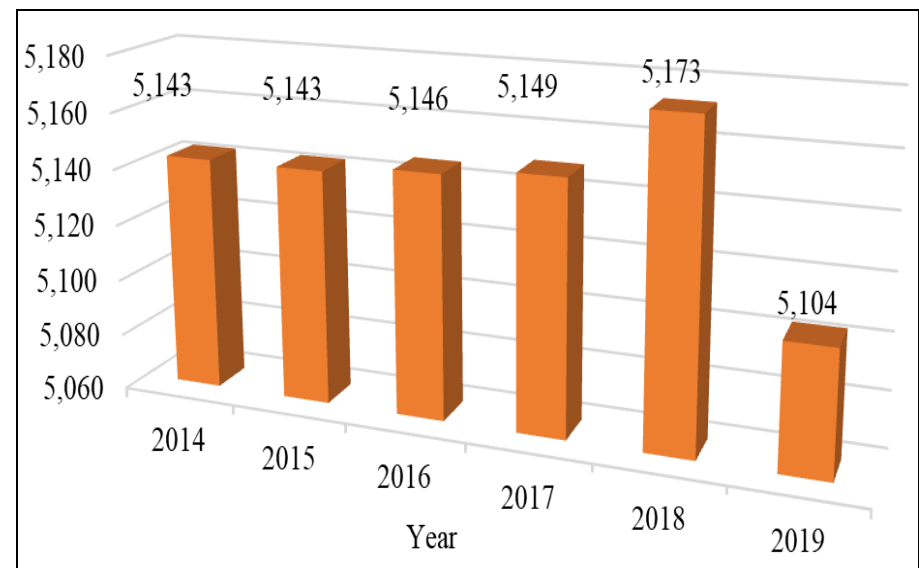

Figure 3. Population Development of Sawarna Village (people) (Source: Kecamatan Bayah Dalam Angka 2019, 2019)
Table 1. Parameter Fisik Air di Desa Sarwana Source: Primary data

\begin{tabular}{|c|c|c|c|c|}
\hline Sample Point & No & Conductivity $(\mu \mathrm{S})$ & Turbidity (NTU) & pH \\
\hline \multirow[t]{3}{*}{ Gua Langir } & 1 & $1,356.00$ & 1.45 & 7.45 \\
\hline & 2 & $1,371.00$ & 1.91 & 7.48 \\
\hline & 3 & $1,364.00$ & 1.61 & 7.49 \\
\hline \multicolumn{2}{|l|}{ AVERAGE } & $1,363.67$ & 1.66 & 7.47 \\
\hline \multirow[t]{3}{*}{ Pulau Manuk } & 1 & 580.50 & 30.70 & 7.52 \\
\hline & 2 & 580.80 & 30.90 & 7.49 \\
\hline & 3 & 582.10 & 30.40 & 7.48 \\
\hline \multicolumn{2}{|l|}{ AVERAGE } & 581.13 & 30.67 & 7.50 \\
\hline \multirow[t]{3}{*}{ Cisawarna } & 1 & $1,647.00$ & 4.42 & 7.58 \\
\hline & 2 & $1,824.00$ & 3.88 & 7.61 \\
\hline & 3 & $1,845.00$ & 3.88 & 7.66 \\
\hline \multicolumn{2}{|l|}{ AVERAGE } & $1,772.00$ & 4.06 & 7.62 \\
\hline \multirow[t]{3}{*}{ Ciasem } & 1 & 2.50 & 14.91 & 7.59 \\
\hline & 2 & 2.75 & 15.20 & 7.58 \\
\hline & 3 & 2.49 & 15.45 & 7.59 \\
\hline \multicolumn{2}{|c|}{ AVERAGE } & 2.58 & 15.19 & 7.59 \\
\hline
\end{tabular}

\section{RESULTS AND DISCUSSION}

\section{On Overview of Sawarna Village}

Sarwana is a village which is located $12 \mathrm{~km}$ from the sub-district capital and $139 \mathrm{~km}$ from the capital of Lebak Regency, with an area of 17.70 hectares. The population growth in Sarwana village is shown in Figure 3. The development of the population in Sawarna village in the last 5 years (2014-2019) can be said that there has been no significant change. The mobility of people in and out Sarwana village could viewed from the type of road surface to Sarwana village, it is an asphalt road that can be traversed throughout the year and there is a fixed route to this village. There are 4 operators with signal conditions that cover most of the area of this village. The development of the population in Sawarna village in the last 5 years (2014-2019) can be said that there has been no significant change. For mobility of people in and out Sarwana village could viewed from the type of road surface to Sarwana village, it is an asphalt road that can be traversed throughout the year and there is a fixed route to this village. To develop tourism industry in this area, society may have environmental ethics that linked with tourism, and ecological virtue and literacy are key elements in this process (Holden, 2019). There are shifted from an instrumental ethic as a basis of conduct for the use of nature to more conservation based ethics (Holden, 2003).

\section{Environmental Condition}

To show environmental conditions, water samples were taken at four locations and its physical characteristics were 
measured directly. Table 1 shows the results of measurements of the physical parameters of the water taken at the four sample points. From Table 1, the conductivity of water from 4 sample points have big differences, at Gua Langir from 3 times taken, the average conductivity is $1,363 \mu \mathrm{S}$, not too different with conductivity at Cisawarna (average conductivity is $1,772 \mu \mathrm{S}$. Conductivity at Pulau Manuk is lower compare to Gua Langir and Cisawarna, and the lowest average conductivity is at Ciasem sample point. The measurement of conductivity at this 4 sample points showed the difference because of the influenced of saline water from sea. Conductivity is a measure of water's capability to pass electrical flow. This ability is directly related to the concentration of ions in the water.

Compounds that dissolve into ions are also known as electrolytes. The more ions that are present, the higher the conductivity of water. Likewise, the fewer ions that are in the water, the less conductive it is. Sea water, has a very high conductivity. It means at Gua Langir and Cisawarna, sea wateris higher than the plain water but at Ciasem, plain water from the river still dominant. The next parameter measured is turbidity. Turbidity is the cloudiness or haziness of a fluid caused by suspended solids that are usually invisible to the naked eye. Water almost always contains suspended solids that consist of many different particles of varying sizes. Some of the particles are large enough and heavy enough to eventually settle to the bottom of a container if a sample is left standing (these are the settleable solids).

The highest turbidity is at Pulau Manuk, and the lowest is at Gua Langir. At Pulau Manuk, there is a movement of fish that will breed at a river from the sea. The society around this area, catch the fish using net, and that make a particle of soil muddy the water. Pulau Langir area is a beach with a cave that quite, desolate with few human activity place, and did not give much disturbance to the water. For $\mathrm{pH}$ measurement, all sample point showed the neutral level of acidity. This showed that the water at all sample point is not yet polluted.

\section{Social and Economic Condition}

Bayah District, especially Sawarna village is an agriculture area. Mostly people in this village is farmer especially paddy. They cultivated paddy at wet land or dry land. The harvested area for lowland rice in Sawarna village in 2018 was 641 ha with an average production of 5.28 tonnes / ha, for dry rice, the harvest area was 27 ha with an average production of 3.32 tonnes / ha. Rice production, both paddy and lading, is very low compared to the national rice production which can reach 9 tons / ha. In addition, the production of horticultural crops and fruits from this village is not optimal. For plantation crops, Sarwana village produces a lot of coconut compared to other villages in Bayah District (production in 2018 was 308.70 quintals. In Sarwana village, there are no financial institutions, there is no market, but there are 2 mini markets, 79 inns, 253 kiosks / stalls, and 11 restaurants. From the socio-economic conditions in Sawarna village, it can be seen that the tourism development has a high potential to be carried out in this village.

Agriculture society closed to natural resource, such land, water, and highly depend on it. Environmental behavior from tourist could hard to find, but it could get from more environmentally friendly architectures driven (Juvan and Dolnicar, 2017). Tourist satisfaction and environmental commitment mediated the relationship of the obtain from visiting a destination, as a perceived by tourist with environmentally responsible behavior (He et al., 2018).

\section{Tourism Potential}

With various coastal views, Sarwana village can develop many tourist spots for tourists. If all beach spots are developed, there will be several beaches that provide a different beach tourism experience. Tourism development can be started by opening access to the beach with a wider road and allowing visitors to go directly to the beach. In the current condition, visitors need to take a two-wheeled vehicle and take a small road to get several beaches. This is an obstacle to show the beauty of the beach directly to visitors. The vehicles available to reach the beach are two-wheeled vehicles, generally motorbikes, by paying motorcycle taxi drivers who have not been properly trained in transporting tourists, and also at rates that seem non-standard. From research of the United Arab Emirates as a popular tourism destination, destination resources, destination infrastructure and support services, and the general business environment have a significance influence on the UAE's tourism competitiveness (Michael et al., 2019).

Coaching motorcycle taxi drivers will open up good opportunities in developing tourism in the Sarwana village. Besides being able to take visitors, these ojek drivers can also function as tour guides. Honest behavior and hospitality can attract visitors to come back to Sarwana. In addition to the limited access to the beach in this village there is a lack of lodging availability. Home stays are starting to exist, but further guidance is still needed in the management of home stays, especially in providing cleaning services. The existence of restaurants and inns with low numbers and quality of services can be used as the starting point for the development of tourism support facilities. Community development to provide home stays is also a useful option, so that people can earn income from these tourism activities. However, mentoring and increasing public awareness to provide the best fair and honest service is very important. In the past few years, it happened that one of the restaurants on the Sarwana beach gave unreasonable prices to visitors.

This incident made visitors hesitate to buy food at restaurants around the beach and it is still affecting by restaurant entrepreneurs until now. In fact, this incident had been resolved by village officials and community leaders by imposing sanctions in the form of prohibiting selling for several months. This shows that the structure of the community still upholds community values and there are still community values that are followed. This also shows, very important to evaluate the Sarwana as a tourism destination. Evaluation of Zhangjiajie, China as a tourism destination using 4E rubric of economiy, efficiency, effectiveness, and environmental quality, showed significance event, natural disaster, and financial crises influence performance most (Luo, 2018). Study about the tourism evaluation in this area will take an important phase in development of this destination. 


\section{CONCLUSION}

The village of Sawarna with a very diverse coastal landscape has the potential to be developed as a tourist destination. Sustainable tourism development can be achieved, considering that the environmental impact, which is seen from the physical characteristics of the water, is still not polluted. Tourism development can increase people's income and ultimately improve their welfare. Develop this area to become the tourism destination need to highly consider about social, economy and environmental aspects at a same time.

\section{Acknowledgement}

This research received funding from the Ministry of Education, Research and Technology and Technology of the Republic of Indonesia to carry out a higher education cooperation grant funding scheme.

\section{REFERENCES}

Ahmad, F., Draz, M.U., Su, L., Ozturk, I., \& Rauf, A. (2018). Tourism and environmental pollution: Evidence from the One Belt One Road provinces of Western China. Sustainability (Switzerland), 10(10), 1-23. https://doi.org/10.3390/su10103520

Armenski, T., Dwyer, L., \& Pavluković, V. (2018). Destination Competitiveness: Public and Private Sector Tourism Management in Serbia. Journal of Travel Research, 57(3), 384-398. https://doi.org/10.1177/0047287517692445

Biggs, R., Vos, A., De, Preiser, R., Clements, H., Maciejewski, K., \& Schlüter, M. (2021). The Routledge Handbook of Research Methods for Social-Ecological Systems. In The Routledge Handbook of Research Methods for Social-Ecological Systems. https://doi.org/10.4324/9781003021339

Danish, \& Wang, Z. (2018). Dynamic relationship between tourism, economic growth, and environmental quality. Journal of Sustainable Tourism, 26(11), 1928-1943. https://doi.org/10.1080/09669582.2018.1526293

Gómez-Vega, M., \& J Picazo-Tadeo, A. (2019). Ranking world tourist destinations with a composite indicator of competitiveness: To weigh or not to weigh? Tourism Management, 72(September 2018), 281-291. https://doi.org/10.1016/j.tourman.2018.11.006

He, X., Hu, D., Swanson, S.R., Su, L., \& Chen, X. (2018). Destination perceptions, relationship quality, and tourist environmentally responsible behavior. Tourism Management Perspectives, 28(April), 93-104. https://doi.org/10.1016/j.tmp.2018.08.001

Hill, J., \& Gale, T. (2012). Ecotourism and environmental sustainability: An introduction. In Ecotourism and Environmental Sustainability: Principles and Practice.

Holden, A. (2003). In need of new environmental ethics for tourism? Annals of Tourism Research, 30(1), 94-108. https://doi.org/10. 1016/S0160-7383(02)00030-0

Holden, A. (2019). Environmental ethics for tourism- the state of the art. Tourism Review, 74(3), 694-703. https://doi.org/10.1108/TR-03-2017-0066

Juvan, E., \& Dolnicar, S. (2017). Drivers of pro-environmental tourist behaviours are not universal. Journal of Cleaner Production, 166, 879-890. https://doi.org/10.1016/j.jclepro.2017.08.087

Lucchetti, M.C., \& Arcese, G. (2014). Tourism management and industrial ecology: A theoretical review. Sustainability (Switzerland), 6(8), 4900-4909. https://doi.org/10.3390/su6084900

Luo, W. (2018). Evaluating tourist destination performance: Expanding the sustainability concept. Sustainability (Switzerland), 10(2). https://doi.org/10.3390/su10020516

Michael, N., Reisinger, Y., \& Hayes, J.P. (2019). The UAE's tourism competitiveness: A business perspective. Tourism Management Perspectives, 30(February 2019), 53-64. https://doi.org/10.1016/j.tmp.2019.02.002

Paramati, S.R., Shahbaz, M., \& Alam, M.S. (2017). Does tourism degrade environmental quality? A comparative study of Eastern and Western European Union. Transportation Research Part D: Transport and Environment, 50, 1-13. https://doi.org/10.1016/j.trd.2016.10.034

Pulido-Fernández, J.I., Cárdenas-García, P.J., \& Espinosa-Pulido, J.A. (2019). Does environmental sustainability contribute to tourism growth? An analysis at the country level. Journal of Cleaner Production, 213, 309-319. https://doi.org/10.1016/j.jclepro.2018.12.151

Sun, Y.Y. (2019). Global Value Chains and National Tourism Carbon Competitiveness. Journal of Travel Research, 58(5), 808-823. https://doi.org/10.1177/0047287518781072

Tang, Z. (2015). An integrated approach to evaluating the coupling coordination between tourism and the environment. Tourism Management, 46, 11-19. https://doi.org/10.1016/j.tourman.2014.06.001

Zheng, Q.J., Xu, A.X., Kong, D.Y., Deng, H.P., \& Lin, Q.Q. (2018). Correlation between the environmental knowledge, environmental attitude, and behavioral intention of tourists for ecotourism in China. Applied Ecology and Environmental Research, 16(1), 51-62. https://doi.org/10.15666/aeer/1601_051062

*** BPS Bayah Sub District. (2020). Kecamatan Bayah Dalam Angka 2019.

Article history: Received: 07.07.2021 Revised: 14.10.2021 Accepted: 30.11.2021 Available online: 31.12 .2021

